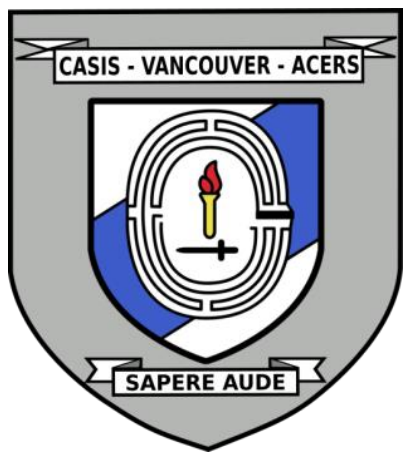

\title{
RUSSIA AND INFORMATION POWER
}

Date: November 23, 2021

Disclaimer: This briefing note contains the encapsulation of views presented by the speaker and does not exclusively represent the views of the Canadian Association for Security and Intelligence Studies.

\section{KEY EVENTS}

On November 23, 2021, Dr. Kevin Riehle, Associate Professor at the University of Mississippi, presented on Russia and Information Power at the 2021 CASIS West Coast Security Conference. The presentation was followed by a question and answer period with questions from the audience and CASIS Vancouver executives. The key points discussed were Russia's foreign policy goals in its information warfare campaign, as well as how Russia exploits information and wields military and diplomatic power as levers to accomplish its political and strategic goals.

\section{NATURE OF DISCUSSION}

\section{Presentation}

Dr. Riehle's presentation centered on how Russia's information actions can simultaneously address multiple objectives in concert with all the other levers of national power it has available. Dr. Riehle also discussed how Russia has justified its military activities based upon narratives regarding NATO and US aggression and how Russian covert sabotage operations have occurred in the same space as information activities.

\section{Question Period}

During the question and answer period, the dilemma between balancing domestic rights and freedoms with state security interests was discussed. Emphasis was placed on developing a response that determines the sources of foreign interference in domestic dialogues rather than muting domestic dialogue through censorship and abolishment of freedom of speech. 


\section{BACKGROUND}

\section{Presentation}

Dr. Riehle began his presentation by expressing that to understand Russian information warfare, we need to establish what Russia is trying to achieve. Dr. Riehle stated that Russia has a discernable list of national security objectives, which include protecting the Putin regime, protecting the post-Soviet state, dividing and disrupting the North Atlantic Treaty Organization (NATO) and the European Union (EU), and counterweighting the United States (US).

Dr. Riehle then stated that Russia employs overt and covert information actions-use of the information space-to enhance its own messages and denigrate the messages of its adversaries. It does this in concert with all its other levers of national power. Consistent themes across overt and covert realms include Russia's portrayal of itself as a victim of a concerted, US-led anti-Russia campaign in the world; Russia's portrayal of Ukraine as a fascist, corrupt state; Russia's portrayal of the US as the source of instability in the world; Russia's portrayal of itself as the savior of the world during World War II, labeling of any action that diminishes that role as 'Russia-phobia'; Russia's portrayal of NATO as a threat to global security; and Russia's portrayal of the EU as being on the verge of collapse.

Dr. Riehle noted that Russia uses its information lever differently depending on the nature of the target and how the target fits into Russia's national security objectives. The objectives remain the same, but the methods may differ. Often, operations on a single target can achieve multiple objectives simultaneously. Arguably, Russia achieved its intended objectives of denigrating Ukrainian sovereignty and tying Ukraine to an aggressive anti-Russia US by portraying Ukraine as the US-backed aggressor in the Russia-sponsored separatist insurgency in the Donbass region. This was allegedly achieved by labeling Ukraine as a fascist state through hacking the Ukrainian Ministry of Defense email server and inserting false inflammatory emails. Russia then claimed to have intercepted the emails and revealed them publicly as if they were authentic. Moreover, using the information lever in this manner fulfills the Russian priority of counterweighting the US in the information space.

In addition, Dr. Riehle pointed out that Russia likely provided informational support to an anti-Ukrainian campaign during a 2016 referendum in the Netherlands on whether the Dutch parliament would ratify Ukraine's application for an EU association agreement. This gave power to anti-EU Dutch activists to 
portray Ukraine as a corrupt, undemocratic state that did not deserve closer ties with the EU. The primary objective of these efforts was to damage Ukraine's attempts to reduce its dependence on Russia and assert its own sovereignty.

The above illustrations of targeting Ukraine demonstrate how these activities simultaneously serve to achieve the Russian objective of building a powerful post-Soviet state, while also portraying the US as a destabilizing force in the world (via the false emails), which can be used to divide and disrupt NATO (via supporting anti-EU activists). Although Ukraine is the primary target, these actions can be used to affect multiple other targets.

In addition to targeting specific states, Dr. Riehle argued that Russia also uses information to support right-wing political groups in Europe to divide and disrupt NATO and the EU. These right-wing political groups are staunchly anti-NATO and EU-skeptic and use their power to advance these positions. During visits to Russia, these groups have also vocalized support for Russia's position on Ukraine.

Dr. Riehle stated that Russia uses a variety of channels in the information space to achieve these objectives. Overt channels include Russian reactions to US/NATO exercises, which Russia pronounces as threatening and destabilizing, thus leading to justification for Russian military exercises, military build ups on Ukraine's border, military support to Belarus, and military modernization across Russia. In recent years, Russia has used state-sponsored media to spread narratives blaming the US for COVID-19 and claiming COVID-19 will end the EU. This is accompanied by diplomatic moves to support Russia's European allies while isolating countries that oppose Russian policies.

Additionally, Russia uses covert channels, or Russian-created illicit channels, to dump or leak politically damaging information to websites, such as Wikileaks, Dr. Riehle noted. Alternatively, it creates websites such as DC leaks, hiding the Russian hand behind the collection and dissemination of the information.

Dr. Riehle concluded his presentation by pointing out that Russia uses nonRussian overt media channels to insert politically damaging or divisive information to foment dissent or create confusion; for example, the disinformation campaign around the shooting down of flight MH17 in which Russia provided conflicting information across multiple channels, including foreign channels. Furthermore, in 2015/16, Russia allegedly promoted divisive Facebook advertisements in the leadup to the US election, and in 2017, Russia allegedly peddled a false story about German soldiers sexually assaulting a girl

The Journal of Intelligence, Conflict, and Warfare Volume 4, Issue 3 
in Lithuania. According to Dr. Riehle, the current use of this last channel arguably resembles a Russian information warfare technique used in the Cold War by way of initially inserting information into a non-Russian channel then rebroadcasting and reinforcing it on Russian media channels.

\section{Question Period}

Dr. Riehle stated that it is critical for Western states to balance national security with rights and freedoms. It was emphasized that Western states must determine both the nature of the information generated by foreign states and source of such information. In a democratic society, there is always a conflict between security and openness which has been discussed incessantly. The two have to work together and in doing so can uncover the reality of what is happening. In this sense, the maintenance of open dialogue can determine the source and manner of foreign interference rather than draconian measures such as the prohibition of dialogue and debate, which could obscure and bury signals of foreign interference. This is easier said than done. There are often foreign actors that exploit the internal division of target states to their own advantage. Thus, the national security community needs to be conscious of external influence in the domestic dialogue of rights and freedoms.

\section{KEY POINTS OF DISCUSSION}

\section{Presentation}

- Russia uses information warfare to accomplish its policy objectives through overt and covert use of the information space.

- Russia's national security objectives include protecting the Putin regime, protecting the post-Soviet state, dividing and disrupting NATO and the EU, and counterweighting the US.

- Some of Russia's consistent themes across overt and covert realms include portraying itself as a victim of a concerted, US led anti-Russia campaign in the world; portraying Ukraine as a fascist, corrupt state; portraying the US as the source of instability in the world; and portraying NATO as a threat to global security.

- Russia uses information warfare in concert with other levers, which include military and political power, to accomplish its policy objectives.

- Russia's information actions simultaneously address multiple national security objectives in concert with all the other levers of national power including diplomacy, military power, and covert sabotage. 


\section{Question Period}

- It is critical for Western states to balance national security with rights and freedoms, as well as to determine the nature of the information generated by foreign states and the source of such information.

- When trying to determine where foreign interference is coming from, maintaining an open domestic dialogue can be more effective in countering such interference rather than prohibiting discussion.

\section{(ब) $\Theta \Theta$}

EY NC ND This work is licensed under a Creative Commons Attribution-NonCommercial-NoDerivatives 4.0 International License.

(C) (KEVIN RIEHLE, 2022)

Published by the Journal of Intelligence, Conflict, and Warfare and Simon Fraser University

Available from: https://jicw.org/ 